\title{
Qualitative Assessment of Banking System Institutional Environment
}

\author{
N. Larionova \\ J. Varlamova \\ Kazan (Volga region) Federal University, 18, Kremlyovskaya Street, Kazan, \\ Repablic of Tatarstan, Russian Federation, 420008
}

Doi:10.5901/mjss.2014.v5n18p177

Abstract

The research indicates that the institutional environment is a key feature of the banking system in different countries. The aim of the research is to examine banking system institutional environment from 18 countries of Eurozone. We have used index and grouping tests as the methods of research and analyzed the indicators for the countries with different state of financial system. Due the investigation countries were divided into three groups with particular features which characterizing internal institutional environment of banking system and allowing making international comparison.

Keywords: banking system, institutional environment, external environment, economic development.

\section{Introduction}

Banking sector is the key element of monetary system and the most important factor of country economic development. The state of financial system in Europe was reviewed by D.Scoenmaker, T.Peek, D.Werkhoven, A.Berger $[1,10,11]$. One of the capital characteristics of banking system is its institutional environment. This aspect is considered in works of Y.Fang, I.Yasan, K.Marton, P.Wachtel, M.Zhou. G.J.Lobo [5, 6, 7]. It stands out as an objective factor that influences on the banking system functioning character. Complex of institutes, system of their interrelations, quality of their performed functions, character of regulative influence create framework conditions for individuals, firms, state to reach their goals and to increase their wealth. Financial behavior of economical agents depends not only on economic factors, but also on population's social and cultural characteristics, that directly influence over saving and investing strategies of people.

Thus it's needed to determine and systemize criteria, characterizing quality of banking system institutional environment and allowing assessing its development both in time and in space. We'll investigate institutional environment of banking system from two points of view:

1) external environment that characterizes and forms investment climate as the key element of banking wherein bank is the integral part;

2) internal environment that is expressed by indicators of bank activity.

We can relate to the external environment of banking system such macro and global economy factors as inflation, balance of payments, currency course, consumption of households, FDI, etc. And to the internal environment of banking system (IEBS) we include characteristics of banking system itself that allows to measure dynamics and quality of its development.

Benchmark data, needed for assess of banking system development level, are: assets and liabilities, loans and deposits, capital and reserves, debt securities. But when we turn to the global level we should determine relative indicators permitting to compare levels of development of banking systems in different countries. In this investigation we concentrate our attention on definition of internal environment of banking systems in different countries.

\section{Method}

The research aim is to develop criteria system for assess of quality of internal institutional environment of banking system. The subject of study is banking systems in different countries. The main methods of investigations are index method and method of grouping.

The object of study is countries of Eurozone - 18 countries of European Union, integrated in monetary union, on which territory euro turns freely. European Central Bank provides monetary policy of Eurozone countries. Although all 
criteria are calculated for year 2012 and Latvia joined Eurozone in January 2014, it's also included in this research.

The euro area's financial structure differs from that of other large economies. Financial intermediaries - in particular banks - are the main agents for channelling funds from savers to borrowers. Banks are the primary source of financing for the economy, most obviously in the case of households. As for firms, more than $70 \%$ of the external financing of the non - financial corporate sector - that is, the financing other than by retained earnings - is provided by banks, and less than $30 \%$ by financial markets $[9,12]$.

The analysis method is development of functioning index of banking and economy systems according to official statistics of European Central Bank. As a criterion of IEBS we suggest to use:

1. Ensuring of population with bank institutes $\left(K_{1}\right)$ characterizes number of local units $(\mathrm{N})$ related to 10,000 population (P).

$K_{1}=\frac{N}{P}$

2. Indicators of lending development allow assessing bank activity in provision this kind of service to clients, on the one hand, and demand for financial resources from economical agents on the other hand. They are calculated as ratio of loans to Eurozone residents $(L)$ to GDP in market prices $-K_{2}$, and related to 10,000 population $(P)-$ coefficient $K_{3}$ :

$$
\begin{aligned}
& K_{2}=\frac{L}{G D P} \\
& K_{3}=\frac{L}{P}
\end{aligned}
$$

3. Indicators, characterizing deposits as the main source of commercial banks liabilities, allow assessing bank resources and bank system ability to accumulate people's savings. On the one hand they show degree of people's confidence to banking institutes, on the other hand they show banking system ability to manage effectively people's savings and transform them into investment resources.

This group of indicators includes $K_{4}$ that determines deposits of Eurozone residents (D) rate in GDP:

$$
K_{4}=\frac{D}{G D P}
$$

Coefficient $K_{5}$ reflects deposits volume (D) per 10,000 population (P) and better characterizes population trust to banking system management of private savings:

$$
K_{5}=\frac{D}{P}
$$

Coefficient $K_{6}$ reflects banking system stability from the point of sources for liabilities forming. When people's deposits (D) constitute the main part of commercial bank assets $(A)$ it increases bank reliability and reduces bank risks.

$$
K_{6}=\frac{D}{A}
$$

4. Potential capacity of banking system $\left(\mathrm{K}_{7}\right)$ is determined by GDP volume attributable to one credit organization $(\mathrm{N})$ :

$$
K_{7}=\frac{G D D}{N}
$$

5. Saturation of banking system by GDP assets $\left(K_{8}\right)$ is submitted by rate of banking system assets $(A)$ in GDP:

$$
K_{8}=\frac{A}{G D P}
$$

Partial indices IIEBS are built compared to minimum meaning. General form of partial index can be performed like this:

$$
I i=\frac{X i-X \min }{X \max -X \min }
$$

As partial indices IIEBS coefficients $I_{1}-l_{8}$ similar to indices $K_{1}-K_{8}$ of banking system have been chosen. Partial indices allow comparing countries by calculated criteria, determining in what countries the certain coefficient is higher or lower matching to other countries. Partial indices are intermediate in calculating integral index. Integral index IIEBS is built on the base of arithmetic average of partial indices. The main role of integral index is to reduce amount of coefficients using for comparing banking systems of different countries to one criterion. Countries grouping was made by integral index IIEBS with the help of equal intervals method. 


\section{Results}

On the base of benchmark characteristics of the volume of assets, deposits, loans, number of local units we have created the system of related criteria that allows comparing banking systems according to their dynamics and development level. Criteria reflect structural characteristics of banking system, the degree of its development and correspondence to socialeconomical demands of the country.

Having applied this system of indicators for analysis of Eurozone countries IIEBS we have determined that averagely there are 4 local banks per 10,000 Europeans (see Table 1). The highest ensuring of population with bank institutes $\left(K_{1}\right)$ can be observed in Cyprus and Spain that have 100 and 82 banks per every thousand of population respectively.

Table 1: Indicators of IIEBS*

\begin{tabular}{|l|c|c|c|c|c|c|c|c|}
\hline Country & $\mathbf{K}_{\mathbf{1}}$ & $\mathbf{K}_{\mathbf{2}}$ & $\mathbf{K}_{\mathbf{3}}$ & $\mathbf{K}_{4}$ & $\mathbf{K}_{\mathbf{5}}$ & $\mathbf{K}_{6}$ & $\mathbf{K}_{\mathbf{7}}$ & $\mathbf{K}_{\mathbf{8}}$ \\
\hline Luxembourg & 3.867 & 0.61 & 7.798 & 1.00 & 8.217 & 44.83 & 211.42 & 2.24 \\
\hline Malta & 2.562 & 0.07 & 0.385 & 0.28 & 0.457 & 35.70 & 64.03 & 0.78 \\
\hline Netherlands & 1.474 & 4.19 & 0.818 & 0.18 & 0.632 & 42.54 & 243.04 & 0.41 \\
\hline Portugal & 5.936 & 1.58 & 0.291 & 0.19 & 0.304 & 57.65 & 26.38 & 0.34 \\
\hline Slovenia & 3.381 & 0.17 & 0.179 & 0.10 & 0.179 & 72.44 & 50.82 & 0.14 \\
\hline Slovakia & 1.963 & 0.20 & 0.072 & 0.06 & 0.081 & 74.03 & 67.01 & 0.08 \\
\hline Finland & 2.599 & 1.03 & 0.561 & 0.09 & 0.324 & 29.20 & 137.00 & 0.31 \\
\hline France & 5.871 & 15.94 & 0.676 & 0.19 & 0.606 & 49.03 & 52.98 & 0.40 \\
\hline Estonia & 1.319 & 0.08 & 0.122 & 0.07 & 0.096 & 64.97 & 98.95 & 0.11 \\
\hline Belgium & 3.443 & 1.59 & 0.441 & 0.17 & 0.574 & 58.68 & 98.40 & 0.29 \\
\hline Germany & 4.511 & 14.79 & 0.580 & 0.17 & 0.565 & 55.22 & 73.58 & 0.31 \\
\hline Greece & 3.262 & 1.38 & 0.239 & 0.16 & 0.285 & 71.70 & 53.39 & 0.23 \\
\hline Ireland & 2.321 & 1.27 & 0.914 & 0.28 & 1.016 & 39.80 & 154.08 & 0.71 \\
\hline Spain & 8.146 & 8.59 & 0.447 & 0.22 & 0.484 & 63.38 & 26.98 & 0.35 \\
\hline Italy & 5.476 & 9.65 & 0.416 & 0.15 & 0.386 & 54.44 & 48.17 & 0.27 \\
\hline Cyprus & 10.046 & 0.34 & 0.948 & 0.41 & 0.853 & 57.45 & 20.65 & 0.72 \\
\hline Latvia & 1.956 & 0.10 & 0.085 & 0.04 & 0.046 & 33.21 & 55.64 & 0.13 \\
\hline Austria & 5.304 & 1.77 & 0.698 & 0.17 & 0.633 & 54.64 & 68.83 & 0.32 \\
\hline
\end{tabular}

* [own calculations based on 2, 4]

French and German banks have the biggest ratio of loans to $\operatorname{GDP}\left(K_{2}\right): 15.94$ and $14.79 \%$ respectively. Wherein averagely banking systems of Eurozone countries provide loans completing $3.5 \% \mathrm{GDP}$. Relatively to population $\left(K_{3}\right)$ the situation is different: the biggest amount of loans per 10,000 population is in Luxembourg that can be explained by significant GDP volumes producing by little population. Averagely banks of Eurozone countries give loans in amount $€ 871031$ per 10,000 of population.

Luxembourg is also the leader according to indicators characterizing deposits of the banking systems $-K_{4}$ and $K_{5}$. In this country banks attract deposits composing $1 \%$ of GDP that overtop average criterion of $0.2 \%$ in investigating countries. €8.5 billion is attracted relatively to 10,000 of population in Luxembourg. Wherein, average rate of this index in Eurozone countries is 0.87 .

More than $70 \%$ of banking systems assets in Slovenia, Slovakia and Greece are people's deposits $\left(K_{6}\right)$, it testifies using of deposits as an instrument, increasing banking system stability. Other Eurozone countries use other sources of monies attracting too.

Countries are extremely different according to potential capacity of banking system $\left(K_{7}\right)$. We can distinguish Netherlands and Luxembourg in which this index is in several times bigger than in Eurozone countries. High saturation of banks by GDP assets is noted in Luxembourg where coefficient $\mathrm{K}_{8}$ is $2 \%$ of GDP.

Grouping of countries according to index IIEBS has allowed distinguishing similarities and differences of Eurozone countries banking systems. Figure 1 clearly shows dividing of countries into three groups - countries with high, medium and low meanings of IIEBS index, wherein 16 of 18 countries are in the last group.

The first group of countries with low level of IIEBS index consists of 14 countries. Finland extremely differs from other developed countries of Europe according to banking system development. Though Finland can be compared to France according to GDP level and population, its banking system rapidly stands down starting with number of local units 
and finishing with volume of assets. Latvia also yields to investigating countries. Latvia has minimum deposits level among analyzing countries, wherein amount of banks doesn't make such an effect in economy as banks in Malta and Luxembourg, though there are less of them in these countries comparing to Latvia.

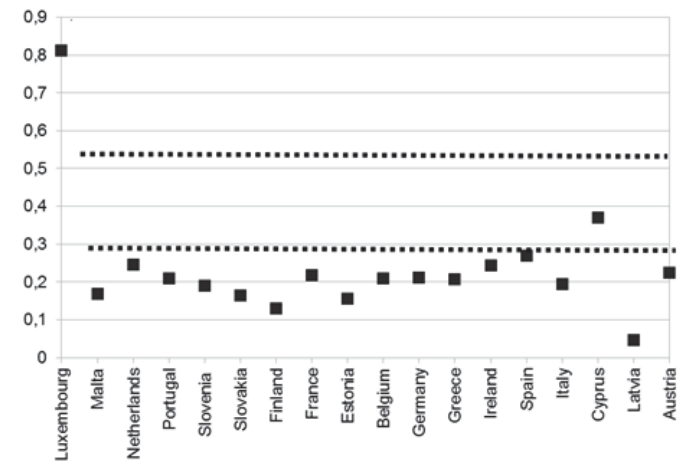

Fig.1 Grouping of countries according to IIEBS index

This group includes countries traditionally perceived as leaders. Thus Italy is home to the fourth largest banking market in Europe (after Germany, UK and France) with total asset value estimated at $€ 4,220$ billion at the end of 2012. It accounts for approximately $9 \%$ of total European banks' assets. The Italian banking sector is totally private. Following the intense privatization process of the 1990s, the state's share in Italian banks is below one percent. Before the start of the privatization process in the 1990s, the state and local public authorities owned around $70 \%$ of total banking assets. This result was achieved both by the sale of the stakes held directly by the state, and through regulatory intervention to encourage the conversion of public banks - mainly savings banks $[2,3,11]$. Wherein France, Germany and Spain rapidly segregate by significant number of credit organizations and volume of assets belonging to banks, volume of granted loans and attracted deposits. Germany and France are similar according to structure of consolidated index. Thus analyzing relative criteria $\mathrm{K}_{1}-\mathrm{K}_{8}$, we can make a conclusion that difference between these two countries is not significant that means similar institutional structure of banking system.

The second group of countries with medium index level consists of Cyprus. It has the maximum rate of coefficient $\mathrm{K}_{1}$ among all investigating countries that allows Cyprus banking system to take place in this group. It may be noted that the banking system in Cyprus is different from other of the Eurozone countries. C.Stephanou singles out the following: first, domestically-owned credit institutions - in the form of both cooperatives and commercial banks - play an important role. Second, even though the biggest domestically-owned banks in Cyprus are small in absolute terms, their large size as a proportion of GDP sets them apart from those of other countries $[4,8,13]$.

The third group includes Luxembourg. Luxembourg leads in 4 of 8 criteria - rate of loans in GDP, loans per 10,000 of population, rate of deposits in GDP and volume of deposits per 10,000 of population. Small in population country producing significant amount of national product is among leaders according to banking system characteristics. It can be explained by the fact that Luxembourg is the leading wealth management center in the euro area. Over the past ten years, Luxembourg's private banking sector developed strong geographical diversification. The share of the three neighboring countries (Belgium, France and Germany) has fallen from $90 \%$ to $49 \%$, while assets under management have increased globally. $19 \%$ of the activity has a geographic origin in the European Union (other than Belgium, France and Germany). All other private banking clients are located around the world (Asia, Latin America, Middle East, etc) [3, 14].

\section{Conclusion}

As a result of analysis we have worked out methodology of institutional environment assessing and have used it for building single system of indicators for different countries. On the base of these indicators we have got integral index characterizing internal institutional environment of banking system in investigating countries and allowing making international comparing.

Grouping of countries by index IIEBS proves preliminary conclusions about peculiarities of institutional environment of banking system. Absolute leader among Eurozone countries is Luxembourg accumulating significant volume of 
deposits and granting enough amounts of loans.

Contrastingly to Luxembourg Latvia, joined Eurozone recently, has the least meanings of IIEBS criteria. Cyprus also stands out group of numerous countries by high ensuring of population with banks.

Internal institutional environment is the base for dynamic and stable development of banking system. Exploited system of criteria and integral index IIEBS can be used for comparative analysis of countries and detection of main tendencies and ways of further improvement of banking system.

\section{References}

A.Berger. Obstacles to a global banking system: «Old Europe» versus «New Europe» // Journal of Banking \& Finance, Volume 31, Issue 7, July 2007, pp.1955-1973

Ajupov A.A. The Design and Use of Swap-Contracts in the Financial Markets // World Applied Sciences Journal, 27(13), 2013, pp. 1-4.

Kirshin I.A., Datsyk A.A., Titov A.V. Forecasting the Dynamics of an Innovative Cycle. - World Applied Sciences Journal (Economics, Management and Finance). - 2013. - №27. - P. 197 - 201.

Glebova I.S., Sadyrtdinov R. and Rodnyansky D. Impact Analysis of Investment Attractiveness of the Republic of Tatarstan on Fixed Investments of its Leading Companies // World Applied Sciences Journal 26 (7): 911-916, 2013.

Y.Fang, I.Hasan, K.Marton. Institutional development and bank stability: Evidence from transition countries // Journal of Banking \& Finance, Volume 39, February 2014, pp.160-176.

Safiullin L.N., Ismagilova G.N., Safiullin N.Z., Bagautdinova N.G. The development of welfare theory in conditions of changes in the quality of goods and services (2012) World Applied Sciences Journal 18 (Special Issue of Economics), pp. 144-149.

I.Hasan, P.Wachtel, M.Zhou. Institutional development, financial deepening and economic growth: Evidence from China // Journal of Banking \& Finance, Volume 33, Issue 1, January 2009, pp.157-170.

K.Kanagaretnarm, G.J.Lobo Effects of international institutional factors on earnings quality of banks // Journal of Banking \& Finance, Volume 39, February 2014, pp.87-106

Bagautdinova, N.G., Malakhov, V.P., Kundakchyan, R.M. Development of management system of manufacturing companies on the basis of management accounting elements // World Applied Sciences Journal, 27(13), 2013, 53-57.

Safiullin L.N., Ismagilova G.N., Gallyamova D.Kh., Safiullin N.Z. 2013. Consumer benefit in the competitive market // Procedia Economic and finance. Volume 5, pp. 667-676 (DOI: 10.1016/S2212-5671(13)00078-6).

The Banking System in Cyprus: Time to Rethink the Business Model? World Bank // Cyprus Economic Policy Review, Volume 5, No. 2, 2011, pp.123-130

The Role of Institutional Factors and Financial Structure // European Central Bank Working Paper Series, April 2013, №1528, p.46.

The State of the Banking Sector in Europe // OECD Economics Department Working Papers, №1102, 36p.

What is the Appropriate Size of the Banking System? // DSF Policy Paper Series, October 2012, №28, 29p. 
